\title{
Archaeological Testing of Site 41BL260 Bell County, Texas
}

Wayne C. Young

Follow this and additional works at: https://scholarworks.sfasu.edu/ita

Part of the American Material Culture Commons, Archaeological Anthropology Commons, Environmental Studies Commons, Other American Studies Commons, Other Arts and Humanities Commons, Other History of Art, Architecture, and Archaeology Commons, and the United States History Commons

Tell us how this article helped you.

This Article is brought to you for free and open access by the Center for Regional Heritage Research at SFA ScholarWorks. It has been accepted for inclusion in Index of Texas Archaeology: Open Access Gray Literature from the Lone Star State by an authorized editor of SFA ScholarWorks. For more information, please contact cdsscholarworks@sfasu.edu. 


\section{Archaeological Testing of Site 41BL260 Bell County, Texas}

\section{Licensing Statement}

This is a work produced for the Texas Department of Transportation (TxDOT) by the report producer. TxDOT and the report producer jointly own all rights, title, and interest in and to all intellectual property developed under TXDOT's contract with the report producer. The report may be cited and brief passages from this publication may be reproduced without permission provided that credit is given to both TxDOT and the report producer. Permission to reprint an entire chapter, section, figures or tables must be obtained in advance from either the Supervisor of the Archeological Studies Branch, Environmental Affairs Division, Texas Department of Transportation, 125 East 11th Street, Austin, Texas, 78701 or from the report producer. 
ARCHAEOLOGICAL TESTING OF SITE 41BL260

BELL COUNTY, TEXAS

Wayne C. Young

Texas

State Department of Highways and Public Transportation

Highway Design Division

December 1987 


\begin{abstract}
Testing of Site 41BL260 along the proposed HM 93 realignment in Be11 County, Texas was undertaken in December 1987 to determine the site's eligibility for inclusion within the National Register of Historic Places, and to determine site depth, cultural context, and archaeological significance. The site is located in a plowed field near the eastern outskirts of Belton, Texas.

Testing results indicate that the site is limited to the present plow zone and that no intact cultural deposits remain within the proposed right-of-way.

Evidence recovered does not support a determination of eligibility for nomination to the National Register of Historic Places.
\end{abstract}


TABLE OF CONTENTS

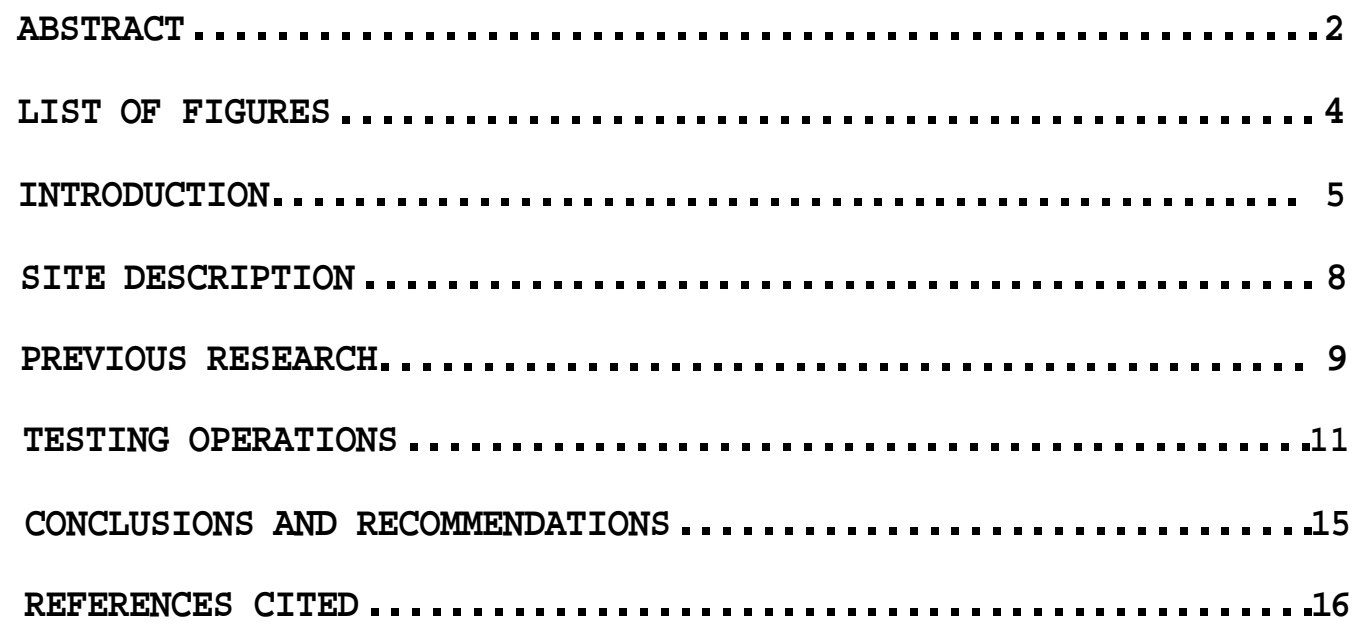




\section{LIST OF FIGURES}

FIGURE 1. Location map of Site 41BL260 in Bell County, Texas......7

FIGURE 2. Map of Site 41BL260 showing location of test units......12 


\section{INTRODUCTION}

Archaeological Site 41BL260 was recorded at the Texas Archeological Research Laboratory of the Balcones Research Center, the University of Texas at Austin, in October 1982 by Texas Water Development Board archaeologists. The site was described as occupying the slopes and crest of a ridge overlooking the confluence of Nolan Creek and the Leon River and occurring within a plowed field near the Temple-Belton regional sewage treatment plant. Observed prehistoric materials included chert chipping debris, burned rock, thick bifaces, a chert cobble hammerstone, and a Gower-like projectile point. Site dimensions were listed as $200 \mathrm{~m} \mathrm{~N}-\mathrm{S}$ by $120 \mathrm{~m} \mathrm{E-W}$ and depth was undetermined. Disturbances included plowing, particularly the plowing of sludge and effluent into the site, and probable crossing of the site by a sewer pipeline. Management recommendations were to avoid if possible, map, surface collect, and test if avoidance was not feasible.

The State Department of Highways and Public Transportation (SDHPT) became involved with the site through plans to relocate portions of FM 93 along a new 150 feet wide right-of-way which will cross the site area. An archaeological survey by a member of the Department's professional cultural resources staff on October 13, 1987 revealed that the site did lie partially within the new right-of-way and that it would be impacted by highway construction. Testing of the site was recommended.

Testing of Site 41BL260 was performed on December 8, 1987 under the auspices of $36 \mathrm{CFR}$, Part 800 to determine eligibility for nomination to the National Register of Historic Places and the cultural significance of the site. Two man-days were spent testing the site. 
Site 41BL260 is located east of Belton, Texas about 0.25 miles south of the present FM 93 bridge over the Leon River (Fig. 1). The site occupies a high terrace along the west bank of the Leon River and is bounded on the east by a paved road leading to the Temple-Belton regional sewage treatment plant and by portions of the Belton sanitary landfill. The southern limits are defined by the paved road and the landfill. The northern and western limits are located in a plowed field and are vague due to a low concentration of prehistoric cultural debitage seen in the furrows. Soils within the field consist of reddish-brown clay subsoils which have been stained by the dumping of sludge onto the site.

Impacts to the site include erosion which has removed the dark upper clay zone typical of the Central Texas area. The site has also been plowed for many years and has had sewage sludge and effluents plowed into it. A 30 inch diameter pipeline carrying raw sewage to the adjacent sewage treatment plant crosses the site within a 100 -feet wide construction easement. Old gravel quarries to the east and south of the paved road may also have removed significant portions of the site. 
This Page Redacted Per THC Policy 
SITE DESCRIPTION

Site $41 B L 260$ is located along a high terrace on the west side of the Leon River near its confluence with Nolan Creek. The terrace system at the site might be more aptly described as a 40 to 50 feet tall, near-vertical bluff consisting of river gravels and conglomerate. The site limit appears to have begun about 50 meters west of the river but this is largely conjecture since the area near the river was destroyed years ago by gravel quarrying operations.

Site limits were difficult to assess. The areas east and south of the plowed field were quarried before being used as a sanitary landfill and any evidence of prehistoric occupations has been destroyed. The plowed field does contain flint flakes scattered lightly over a large area. The field has been plowed for many years and some scattering of debitage beyond the original site limits is to be expected. Debitage was found to extend about 200 meters north-south about 50 meters east-west near the eastern edge of the field. Although debitage was not abundant anywhere, it was most noticeable in a 30 meter wide strip near the east fence and also about 50 meters north and outside the proposed right-of-way boundary.

Vegetation within the field was nonexistent due to plowing. Hackberry and cedar trees were noted along the fence rows. These species along with live oaks and cedar elms are the major arboreal species near the site area. 


\section{PREVIOUS RESEARCH}

A considerable amount of archaeological research has been performed in Bell County, Texas. The county is one of the easternmost tier of counties in Central Texas and has been the base of operations for the Bell County Archeological Society since the 1930's. The county also has seen the construction of large-scale federal projects including Fort Hood, Lake Belton, and Stillhouse Hollow Reservoir which allowed for archaeological investigations. Archaeologically, Bell County is one of the better known Central Texas counties and has provided significant information toward the understanding of prehistoric chronologies in this part of Texas.

Information on the county's prehistory began to be published in the 1930's. Perhaps the earliest reported research was that of Jackson (1935). Several reports were published on the archaeology of Aycock Shelter (Watt 1936, Aynesworth 1936a, 1936b, Lux 1936). Russell (1936) provided an early report on the general archaeology of the county and Watt (1937) reported on a burial site near Little River.

Any publications directly dealing with the county's archaeology during the 1940's have escaped the writer's attention and it is assumed that there was a hiatus in research during this decade. The publication of research findings resumed during the 1950s.

Holden (1951) issued a report on stone beads from the county and Miller and Jelks (1952) reported on excavations at Belton Reservoir. Forrester (1957) reported an unknown type of implement from the county. 
During the 1960s some major sites were excavated and reported. In 1962 Johnson reported on the survey of Stillhouse Hollow Reservoir (Johnson 1962) . Shafer(1963) detailed the findings at the Youngsport Site, a major Early Archaic site in Central Texas. Shafer published their results of 1962 testing in Belton Reservoir. Sorroteal.a (1967) detailed their excavations at Stillhouse Hollow Reservoir and presented the first local chronology for the county.

During the 1970s Shafer presented a paper on the late prehistory of the area (Shafer 1971). Cochran (1974) reported on the Shetland Site. McCormick and Filson (1976) reported on a survey in Copperas Cove and Dibble (1977) reported a survey on portions of Fort Hood. Thomas (1978) presented an overview of the archaeological resources of Fort Hood.

The major work in Bell County during the 1980s has been Fort Hood surveys. Carlson et al. (1983) appear to have produced the most recent publication dealing with the prehistory of Bell County. 


\section{TESTING OPERATIONS}

Archaeological investigation of Site 41BL260 consisted of surface observations, the hand excavation of a 1 meter square test unit, 3 shovel tests, and the machine excavation of 3 backhoe trenches into the site deposits. Testing was limited to the 150 feet wide proposed right-of-way for FM 93.

Surface observations indicated a rather thin scatter of lithic debitage with no major concentrations within the plowed field. Flake debris was somewhat concentrated near the eastern edge of the site. Burned rocks were especially sparse in the right-of-way even though they should have been easily spotted in a clean plowed field. With no indications other than a general surface scatter in a field which has been plowed for decades, testing plans were made to excavate backhoe trenches at 50 meter intervals near the highway centerline to test for buried deposits (Fig. 2).

Backhoe Trench 1 was excavated at the eastern site limit adjacent to the fenceline in an area containing the most-surface evidence. This trench was 4 meters long and one meter deep and failed to reveal any burned rocks, bone, shell, snails, or lithic debitage below the $30 \mathrm{~cm}$ thick plow zone. The eastern edge of the trench contained a $30 \mathrm{~cm}$ thick plow zone of reddish clay typical of Central Texas subsoils. At $50 \mathrm{~cm}$ this zone changed to a reddish clay. The western portion of the trench had been excavated into furrows where sludge had been pumped and had stained the soils a blackish hue to the bottom of the trench. This staining was seen in all other units excavated into the site and has obscured the true soil colors. 


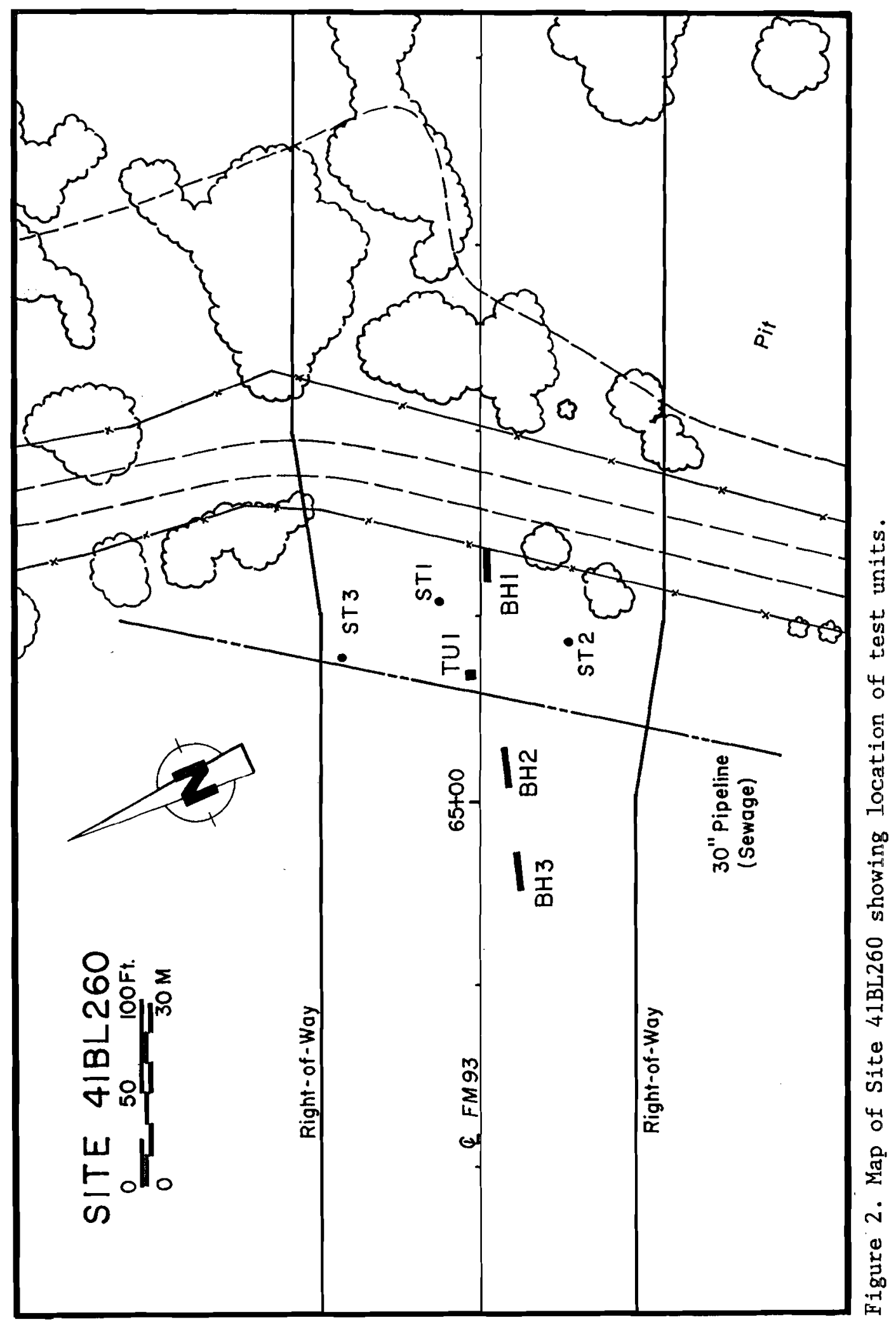


As Backhoe Trench 1 was being excavated a very concerned sewage treatment plant manager arrived and announced that a 30 inch diameter pipe line bringing raw sewage from Temple was buried within the proposed right-of-way. His construction maps showed that the pipeline crossed the right-of-way about 100 feet east of the paved road and that the pipe was buried within a 100 feet wide construction easement.

The location of this pipeline was near where Backhoe Trench 2 was planned. Instead of a backhoe trench in this area, a 1 meter square test unit was excavated to $50 \mathrm{am}$ with negative results. The plow zone was shoveled out until firm clays were reached $(30 \mathrm{~cm})$. Two $10 \mathrm{~cm}$ levels were then excavated and screened through $1 / 4$ inch mesh hardware cloth with no recovery of cultural materials. At $30 \mathrm{am}$ the soils became a blackish red clay which is interpreted as being the same red clay seen at the east end of Backhoe Trench 1.

Backhoe Trench 2 was excavated west of Test Unit 1 and excavated to 90 om below the present surface. This 4 meter long trench also failed to indicate any indications of cultural materials below the plow zone and showed the same black stained soils as the west end of Backhoe Trench 1.

Backhoe Trench 3 was excavated west of Backhoe Trench 3 to $80 \mathrm{~cm}$ depth. The 4 meter long profile failed to indicate any cultural materials. Surface indications suggested that this trench was beyond the site limits. Soils had also been discolored by the sludge pumped onto the field. 
Three shovel tests were also excavated into the site. These circular, $50 \mathrm{~cm}$ deep holes also failed to locate any subsurface cultural materials. Their location is shown in Figure 2.

Excavations were halted after the 3 backhoe trenches, Test Unit 1, and the 3 shovel tests failed to indicate the presence of cultural materials below the present plow zone. No flakes, features, tools, burned rocks, snails, shell, or bone were recovered and the lack of these items is taken to indicate that the site is limited to the plow zone and is without a valid archaeological context. 


\section{CONCLUSIONS AND RECOMMENDATIONS}

Archaeological testing of portions of Site 41BL260 within the proposed FM 93 right-of-way in Bell County has established that the site is a shallow low density prehistoric occupation limited to the $30 \mathrm{~cm}$ thick plow zone. The lack of recovered materials precludes any attempts at site interpretation. A tentative Early Archaic occupation might be postulated by the Gower-like point reported by the site recorders although a single specimen appears inadequate for placing temporal parameters. Perhaps it should be mentioned that this single dart point was found north of the right-of-way and cannot be shown to definitely correlate with the tested portions of the site.

The lack of a valid archaeological context below the present plow zone should negate the need for additional investigations at the site. It is believed that the portions of Site 41BL260 within the proposed right-of-way do not meet the criteria for nomination to the National Register of Historic Places and that the site does not merit State Archeological Landmark status. Those portions of Site 41BL260 beyond the Department's jurisdiction were not tested and a determination of the intactness of deposits cannot be made. No further investigation of Site 41BL260 within the right-of-way is recommended. 
Aynesworth, K.H.

1936a Biographic Studies of Twenty-One Skulls of the Central Texas Indians. Bulletin of The Central Texas Archeological Society 2: $30-34$.

1936b Flint Arrowhead Wounds of Bones as Shown in Skeletons in Central Texas. Bulletin of The Central Texas Archeological Society. $2: 74-80$.

Carlson, David L., Fredrick Bruier, Henry Bruno; and Eli Mishuck

1983 Final Report on Statistically Representative Sample of Sites at West Fort Hood. Report submitted to U.S. Army by Science Applications, Inc. La Jolla, California.

Cochran, Joe F.

1974 The Shetland Site, Bell County, Texas. Paper presented at the annual meeting of the Texas Archeological Society. Dallas.

Dibble, David S.

1977 A Cultural Resource Survey of the Proposed Air Route Surveillance Radar Site, Fort Hood, Texas. Technical Bulletin 19. Texas Archeological Society, the University of Texas at Austin.

Forrester, Robert E., Jr.

1957 Report on an Unknown Type of Implement. Bulletin of the Texas Archeological Society 18:121-126.

Holden W.C. (Editor)

1951 Stone Beads from Bell County. Bulletin of the Texas Archeological Society 22:228.

Jackson, A.T.

1935 Ornaments of East Texas Indians. Bulletin of the Texas Archeological and Paleontologica Society 7:11-28.

Johnson, LeRoy, Jr.

1962 Survey and Appraisal of the Archeological Resources of Stillhouse Hollow Reservoir on the Lampasas River, Bell County, Texas. Texas Archeological Salvage Project, University of Texas at Austin.

Lux, Konrad

1936 A Detailed Report on the Teeth and Supporting Structures as Found in Crania of Aycock Shelter. Bulletin of the Central Texas Archeological Society 2:39-42.

McCormick, O.F., and R.E. Filson

1976 A Report on Archaeological Investigations of Proposed Wastewater Treatment Facilities, Copperas Cove, Texas. Institute of Applied Sciences, North Texas State University. Denton. 
Miller, E.O., and E.B. Jelks

1952 Archeological Excavations at the Belton Reservoir, Coryell County, Texas. Bulletin of the Texas Archeological and Paleontological Society 23:168-217.

Russell, F.B.

1936 Archeology of Bell County. Bulletin of the Central Texas . Archeological Society 249-51.

Shafer, Harry J.

1963 Test Excavations at the Youngsport Site: A Stratified Terrace Site in Bell County, Texas. Bulletinof the Texas Archeological Society 34:57-81.

1971 Late Prehistory of Central Texas, $\mathbf{5 0 0}$ B.C. -1700 A.D. Paper presented at the 74th annual meetinfg of the Texas Academy of Science. Nacogdoches.

Shafer, Harry J., Dee Ann Suhm, and J. Dan Scurlock

1964 An Investigation and Appraisal of the Archeological Resources of Belton Reservoir, Bell and Coryell Counties, Texas, 1962.

Miscellaneous Papers 1. Texas Archeological Salvage Project, University of Texas at Austin.

Sorrow, William M. Harry J. Shafer, and Richard E. Ross

1967 Excavations at Stillhouse Hollow Reservoir. Papers of the Texas Archeological Salvage Project 11. The University of Texas at Austin.

Thomas, George B.

1978 A Survey and Assessment of the Archeological Resources of Fort Hood, Texas. Bulletin of the Texas Archeological Society

$49: 195-240$.

Watt, Frank H.

1936 A Prehistoric Shelter Burial in Bell County, Texas. Bulletin of the Central Texas Archeological Society 2:4-27.

1937 A Gravel Pit Burial Near Little River. Bulletin of the Central Texas Archeological Society 3:80-82. 
COMMISSION

ROBERT H. DEDMAN. CHAIRMAN JOHN R. BUTLER. JR.

RAY STOKER. JR.
STATE DEPARTMENT OF HIGHWAYS

AND PUBLIC TRANSPORTATION

D E W. GREER STATE HIGHWAY BLDG.

11TH \& BRAZOS

AUSTIN. TEXAS 78701-2483

December 14, 1987
ENGINEER-DIRECTOR

R. E. STOTZER, JR.

Testing of Archaeological Site 41BL260

Bell County

FM 93: From IH 35 in Belton to FM 1741

$\mathrm{D}-8 \mathrm{E}$

845.709

1835-02-020

Dr. James E. Bruseth

Deputy State Historic Preservation Officer

Texas Historical Commission

Austin, Texas 78711

Dear Sir:

Reference is made to our letters of December 4 and 9, 1987, relevant to testing of portions of archaeological site 41BL260, a site found partly within the $\mathrm{PM} 93$ roadway right-of-way along the subject project. As indicated to you in our December 9 letter, testing of portions of site 41BL260 was perfomred by a member of the Department's professional cultural resources staff during the week beginning December 7, 1987. Work was performed in accordance with 36 CFR Part 800 and under the Memorandum of Understanding between the Department and the Texas Antiquities Committee.

Enclosed are fifteen copies of a testing report for site 41BL260. This report substantiates the Department's determination that portions of site 41BL260 within the FM 93 roadway right-of-way do not meet the criteria for inclusion within the National Register of 'Historic Places. Further work is not warranted.

Your review and response is requested indicating your concurrence that portions of archaeological site 41BL260 within the FM 93 roadway right-of-way do not meet the criteria for inclusion within the National Register of Historic Places and that further work is not required. The return of your comment within thirty days after receipt of this letter will be appreciated.

Sincerely,

ES

Enclosure

cc: Mr. Mark Denton

Texas Antiquities Committe e

bcc: The Waco District

$\mathrm{FDH}, \mathrm{KCB}, \mathrm{RMB}$,

WCY, AMI, ES
R. E. Stotzer, Jr.

Engineer-Director

$\begin{array}{cc}\text { By : } & \begin{array}{c}\text { Original Signed for } \\ \text { FRANK D. HOLZMANN }\end{array}\end{array}$

Frank D. Holzmann

Chief Engineer, Highway Design 